\author{
Каламан О.Б. \\ кандидат економічних наук, доцент \\ кафедра менеджменту і логістики \\ Одеська національна академія харчових технологій \\ вул. Канатна, 112, м. Одеса, Україна, 65039 \\ E-mail: buxgalter11@ukr.net
}

\title{
АНАЛІЗ СТАНУ ТА ОСОБЛИВОСТІ УПРАВЛІННЯ ПІДПРИЕМСТВАМИ ВИНОГРАДАРСЬКО-ВИНОРОБНОГО ПІДКОМПЛЕКСУ
}

Розглянутий сучасний стан ринку продукції виноградарства. Показані основні тенденції розвитку виноградарсько-виноробної галузі країни. Описані проблеми агропромислового підкомплексу України. Зображено скорочення площ, врожайності та валового збору винограду як наслідок нераціонального розвитку підкомплексу. Виявлено гострі проблеми галузі в сучасних реаліях. Зображені специфічні особливості фрунцціонування підприємств виноградарсько-виноробної галузі. Запропоновані шляхи поліпшення стану галузі.

Ключові слова: агропромисловий підкомплекс, ринок, виноградарство, виноробство, виробництво, підприємство.

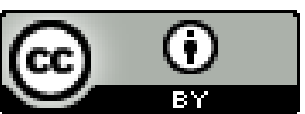

Постановка проблеми та її зв'язок з вважливими науковими та практичними задачами. Сьогодні сфера виробництва $є$ пріоритетною для розвитку країни. Починаючи 3 мікрорівня і закінчуючи сферою управління на рівні держави всі учасники ланцюга зацікавлені в ефективній діяльності кожної складової АПК. Одним із найбільш традиційних галузей АПК України завжди була і залишається виноградарсько-виноробна. Вона за всіма оцінками фахівців вважається найбільш пріоритетною та рентабельною. Але постійний кризовий стан не оминув і iі, тому вона поступово знижує свій рівень рентабельності. Сьогодні перед галуззю постає низка економічних, соціальних, наукових і управлінських проблем, рішення яких потребує негайного втручання.

Аналіз останніх публікацій по проблемі. Проблеми ефективного економічного розвитку виноградарсько-виноробного підкомплексу в Україні знайшли відображення в працях відомих науковців, серед яких А.М.Авідзба, В.А.Виноградов, А.М.Бузні, В.А.Загоруйко, Г.Г.Валуйко, О.М.Гаркуша, І.Г.Матчина, Н.П.Петруня, та деякі інші.

Формулювання цілей дослідження. Проте питання, пов'язані безпосередньо з управлінням сучасним станом, та перспективи щодо можливого подальшого розвитку галузі все ще залишаються недостатньо дослідженими. Метою статті є зображення основних аспектів управління станом та перспекти- вами розвитку виноградарсько-виноробного підкомплексу.

Виклад основних результатів та їх обгрунтування. До провідних галузей економіки України, які мають перспективи виходу на світовий ринок, традиційно відносять виноградарсько-виноробне виробництво. Серед міжгалузевих АПК України виноробство займає окреме специфічне місце. Його основні види продукції: вино, шампанське, коньяк - за своїми споживчими властивостями є унікальними і затребуваними як на внутрішньому, так і на зовнішньому ринках. Однак, в умовах глобалізації ринку вина перспективи розвитку національного виноградарства і виноробства є занадто жорсткими і альтернативними: або якісне зростання, або стагнація 3 наступним різким спадом виробництва. Тому має бути вироблений універсальний механізм взаємодії підприємств галузі, що займаються окремими елементами виробничого процесу.

За останні 50 років площі виноградних насаджень в Україні скоротились у 18 разів (213,3 тис. га). Так, у 1965 р. виноградники займали 262 тис. га, у 1970 р. - 287 тис. га, у 1975 р. - 275 тис. га, у 1980 р. 248 тис. га, у 1985 р. - 209 тис. га, у 1990 р. 175,5 тис. га, у 1995 р. - 155 тис. га, у 2000 р. 109,6 тис. га, і в 2005 р. - 95,5тис. га., у 2014 році - 48,7 тис. га. По Одеській області теж можна спостерігати негативну тенденцію, що зображена у таблиці 1 [7]. 
Аналіз зміни площ виноградних насаджень в Одеській області, тис. га

\begin{tabular}{|l|c|c|c|c|c|c|c|c|c|}
\hline \multicolumn{1}{|c|}{ Показники } & 1990 & 1995 & 2000 & 2005 & 2010 & 2012 & 2013 & 2014 & $\begin{array}{c}2014 \text { p. } \\
\text { до 1970 p. }\end{array}$ \\
\hline Площа виноградних насаджень & 62,9 & 59,4 & 44,1 & 40,4 & 35,9 & 32,9 & 31,6 & 30,2 & 48,01 \\
\hline у тому числі у плодоносному віці & 55,1 & 53,7 & 40,3 & 34,3 & 28,0 & 29,1 & 28,5 & 27,5 & 49,91 \\
\hline
\end{tabular}

Нестійкою була й врожайність винограду. Так, у період з 1960 по 1970 рік вона становила в середньому 34,3 - 37,6 ц з гектару. У подальшому за рахунок удосконалення технологій вирощування ви нограду вдалося помітно підвищити його врожайність. Так, у 1971 р. було зібрано 143,9 ц з гектару, у 1973 р.- 61,4 ц, у 1974 р. - 46,7 ц, і в 1975 р. - 59,1 ц. У 1976 - 1980 рр. середня врожайність становила 44,7 -ц/га, у 1981-1985 pp. - 54,0 ц/га, у 1986-1990 pp. - 57,2 ц/га. 31991 по 1995 рік врожайність знизилась від 47,6 ц до 33,2 ц/га. Але у подальші роки ії вдалося значно підвищити. Так у 2014 році вона зросла до 98,6 ц/га. Що, як відомо, дотягує до показників сучасних Свропейських країн високоефективного виноградарства [7].

В свою чергу, достатньо вагомим показником ефективного вирощування винограду як сировини для подальшої переробки вважається валовий збір. Так у 1975 році в Україні він був зазначений на рівні 1187 тис. т. В подальшому спостерігалось значне скорочення площ виноградних насаджень, тому знижувались і валові збори. У 2001-2004 рр. вони становили $336-374$ тис. т. Таким чином за 10 років в Україні валовий збір винограду знизився у три рази, а загальна площа виноградних насаджень скоротилась на 73,6 га, при середній врожайності 30 ц/га, проти рівня 40 ц/га - достатнього для забезпечення беззбиткового ведення галузі. У 2014 році ситуація незначно, але поліпшилась, збільшивши за 10 років валовий збір до 435,6 тис. т. Окреме гостре питання стосується вікової структури виноградних насаджень: 25\% площ мають свій вік до 20, 35\% - до 30 років і $25-30 \%$ - уже понад 30 років. При цьому очікувати від таких старих і зріджених плантацій віддачі високої неможливо [7].

Найменше використовували виноград власного виробництва підприємства Закарпатської (11\%) i Одеської (12\%) областей. Середня ціна закупівлі винограду для переробки зросла з 2038 грн. за 1 тонну в 2008 р. до 3283 грн. в 2014 р. (на 0,4\%). Це відбулося в основному за рахунок підвищення повної собівартості виробництва 1 т винограду до 2084 грн. це дозволило отримати рентабельність виноградарськими підприємствами на рівні 57,5\% [2].

Найбільш поширеними сортами на території України залишається впродовж вже тривалого періоду «Ркацителі» і «Аліготе» - по 13\% від загального обсягу переробленого винограду. Виробництво виноградного вина в середньому за останне десятиліття скоротилося в цілому по Україні на 46,3\%. Основни- ми конкурентами на українському ринку алкогольних напоїв є винороби Німеччини, Чилі, Угорщини, Італії, Франції, Молдови, Болгарії, Македонії. За якістю винопродукція, ввезена 3 країн далекого зарубіжжя, значною мірою відрізняється від виробленої в Україні та країнах СНД. Якщо зовнішнє оформлення і стабільність ввезеної продукції, без сумніву, привертає українського споживача, то іiі органолептичні характеристики часто поступаються українським. Внаслідок цього спостерігається зменшення виробництва i реалізації української виноробної продукції, зниження іiї експорту[3].

Більше того, зі вступом України до СОТ для виноградарства, орієнтованого в основному на виробництво сировини для вітчизняної виноробної промисловості, що не подолали повною мірою наслідки останнього двадцятиріччя не вступили у стадію сталого розвитку, додалося і ряд системних проблем, насамперед, пов'язаних з формуванням недосконалого ринку вина [10]. Зокрема, вже на першому етапі товарної інтервенції збільшилася пропозиція дешевих виноматеріалів для вторинного виноробства та ін. Відмічати необхідність впровадження механізму чистої конкуренції, рівні можливості країн-учасниць COT i, зокрема України, на міжнародному ринку виноробства не доводиться. У той час, як вітчизняні виробники вин прагнуть всіма силами зберегти їх кількісне і якісне виробництво, європейські винороби прагнуть заповнити український ринок «надлишками» своєї продукції, яка не знайшла збуту на внутрішньому ринку. Безумовно, здорова конкуренція українському аграрному ринку в цілому може піти на користь, проте відносно виноробної продукції слід сказати, що вина України та Європи - це два абсолютно різних продукти як за органолептичними властивостями, так і по споживчим вподобанням, і конкуренція тільки за ціновою ознакою може згубно позначитися на збереженні самобутності вітчизняного виноробства.

В даний час для світового ринку вина характерні наступні тенденції. По-перше, спостерігається стабілізація площ під виноградниками. По-друге, спостерігається зростання виробництва вина, в 2014 році - 271 млн. гектолітрів, що лише на 6\% скоротився відносно 2013 року. Також, згідно з проведеним нами дослідженню частка традиційних «винних» держав, насамперед Італії та Франції, поступово знижується. На ринку зростає конкуренція з боку нових виноробних країн, таких як Чилі, Австралія, Південна 
Африка. У той же час в традиційних країнах - імпортерах вина - США, Німеччини, Великобританії, Японії, споживання вина динамічно зростає. Першою у списку залишається Франція 46,2 млн. гл., потім Італія - 44,4 млн. гл, третє місце у Іспанії - 37 млн. гл., а лише потім США - 22,5 млн. гл., Чилі - 10 млн. гл., Нова Зеландія - 3,2 млн. гл. [5].

Виноградно-виноробний підкомплекс перспективна складова для систематичного, сталого та ефективного розвитку аграрного сектору України. Незважаючи на винятково сприятливі грунтові і кліматичні умови для обробітку винограду та виробництва високоякісних вин, спостерігаються наступні несприятливі тенденції, які пов'язані в більшості випадків 3 недостатністю фінансування та недосконалістю чинної законодавчої бази:

- постійне скорочення площ під виноградниками;

- зменшення обсягів переробки винограду в деяких областях України;

- збільшення ціни закупівлі винограду для переробки внаслідок підвищення цін на виноград;

- скорочення виробництва вин.

Слід також зауважити, що найбільші виноградні насадження доцільно розташовувати у найкращих для розвитку цієї галузі мікрозонах, де можна одержувати продукцію найліпшої якості. Але, безумовно, розумно сплановані та раціонально розташовані площі виноградників мають бути спеціалізованими та потужними виноградарськими господарствами, які б змогли забезпечити значне зростання валових зборів винограду.
Треба відзначити важливу роль енегро- та ресурсозберігаючих технологій, які на сьогодні тільки впроваджуються у цій галузі АПК, підвищення рівня механізації в галузі. Для цього в Україні доцільно налагодити випуск відповідних машин та механізмів - енергозберігаючих та комбінованих. Однак не слід допускати надмірного спрощення технології вирощування винограду. Для досягнення комплексного ефекту потрібне застосування усіх існуючих агроприйомів.

Висновки і перспективи подальших досліджень. Таким чином, на нашу думку, вирішення поставлених перед галуззю виноградарства завдань потребує розробки відповідного покращеного комплексу економічних та правових заходів, що зможуть бути використані у реаліях практичного виробництва. Їх реалізація допоможе значно покращити стан підкомплексу, що склався сьогодні у країні, вдосконалити ефективне використання його резервів, підвищити якість його продукції та бути ефективним допоміжним фактором для його розвитку.

Виноградарство завжди було, є і буде високоефективною галуззю аграрного виробництва і при правильній економічній політиці $є$ конкурентоздатним разом 3 іншими галузями агропромисловості України. Однак, незважаючи на всі розглянуті проблеми і кризовий стан виноградарсько-виноробної галузі в Україні, у вітчизняного виноробства та українських виноробних компаній $є$ всі шанси зайняти прибуткову нішу на ринку тільки за умови слідування світовим тенденціям ринку вина.

\section{Література}

1. Історія виноградарства [Електронний ресурс] - Режим доступу : http://vinograd.info/info/grozdyazdorovya/istoriya-vinogradarstva.html

2. Стан виноробної галузі у світі [Електронний ресурс] - Режим доступу : http://takeprofit.org/economicnews.php

3. Гаркуша О.М. Проблеми розвитку виноградарсько-виноробного підкомплексу України / О. М. Гаркуша // Економіка АПК. - 2008. - № 11. - С.3-5.

4. Балян А.В. Стан європейського виноградарства і напрями підвищення ефективності підкомплексу в Україні / А. В. Балаян // Економіка АПК. - 2007. - № 3. - С.16-22.

5. Серпуховитина К.А. Современные направления развития виноградарства в условиях интеграции отечественной продукции в мировой рынок / К. А. Серпуховитина // Виноделие и виноградарство. -2005 . - № $1 .-$ C.10-11.

6. Економіка виноградно-виноробного господарства в ринкових умовах України [Текст] / [О.В. Сидоренко, І.Г. Матчина, А.Н. Бузни и др.]. - Миколаїв: МДАУ, 2006. - 312 с.

7. Державний комітет статистики України - 2014p. [Електронний ресурс]. - Режим доступу : www.ukrstat.gov.ua

8. Загоруйко В.О. Місце вин України на європейському ринку / В. О. Загоруйко // Вісник аграрної науки. - 2004. - № 12. - С.53-55.

9. Авідзба А.М. Підготовка виноробної галузі до вступу України у СОТ / А. М. Авідзба // Вісник аграрної науки. - 2006. - № 11. - С.5-10.

10. Про виноград та виноградне вино : Закон України №2662-IV от 16.06.2005 г. // Відомості Верховної Ради України. - 2005. - № 31. - Ст. 419. 


\author{
Каламан О.Б. \\ кандидат экономических наук, доцент \\ кафедра менеджмента и логистики \\ Одесская национальная академия пищевых технологий \\ ул. Канатная, 112, г. Одеса, Украина, 65039 \\ E-mail: buxgalter11@ukr.net
}

\title{
АНАЛИЗ СОСТОЯНИЯ И ОСОБЕННОСТИ УПРАВЛЕНИЯ ПРЕДПРИЯТИЯМИ ВИНОГРАДАРСКО-ВИНОДЕЛЬЧЕСКОГО ПОДКОМПЛЕКСА
}

В статье рассмотрены основные проблемы виноградарско-винодельческой отрасли страны: самостоятельность и отсутствие скоординированности действий каждого элемента цепи производственного процесса, отсутствие единого механизма действия предприятий виноградарских и винодельческих, если они не являются одним предприятием. Первые пытаются свою готовую продукцию продать как можно дороже для дальнейшей переработки. А вторые - найти самых дешевых поставщиков качественного виноматериала. Такой процесс приводит к проблемам во всей отрасли. Но это составляет лишь часть основных проблем для предприятий виноградарско-винодельческого подкомплекса. Статья показывает перечень основных сложностей отрасли. Совокупность таких проблем затрудняет выход произведенной продукции отрасли на передовые современные европейские рынки. Возникает вопрос о необходимости анализа потребностей и предпочтений внешнего рынка.

Показаны основные трудности в законодательном поле: несовершенное отечественное законодательство и несистемность действий отдельных законодательных актов приводит к стагнации и упадку отрасли, что в результате фрормирует дополнительные сложности для фрункционирования виноградарско-винодельческих предприятий и агропромышленного комплекса в целом. Также рассмотрено современное состояние рынка продукции виноградарства, что позволяет сделать определенные выводы относительно потенциальных возможностей развития отрасли. Основные субъекты и их рациональное взаимодействие позволит каждому получить свой положительный эффект.

В статье наглядно изображено сокращение площадей виноградников, снижение урожайности и валового сбора винограда, что является следствием нерационального развития подкомплекса. Выявлены острые проблемы отрасли в современных реалиях. Изображены специфические особенности функционирования предприятий виноградарско-винодельческой отрасли. Предложены пути улучшения состояния отрасли и направления действия для улучшения ситуации как на уровне предприятия, так и на уровне подкомплекса.

Ключевые слова: агропромышленный комплекс, рынок, виноградарство, виноделие, производство, предприятие.

\author{
Kalaman O.B. \\ Ph.D. in Economics, Associate Professor \\ Department of Management and Logistics \\ Odessa National Academy of Food Technologies \\ Kanatna Street, 112 , Odessa, Ukraine, 65039 \\ E-mail: buxgalter11@ukr.net
}

\section{ANALYSIS OF THE CONDITION AND PARTICULARITIES OF THE MANAGEMENT ENTERPRISES OF VITICULTURE AND WINEMAKING SUBCOMPLEX}

This article describes the basic problems of agriculture Ukraine subcomplex. The autonomy and lack of the action coordination were shown for each chain element of the production process. The great importance was indicated of viticulture and winemaking in the score of the effective functioning of the entire agricultural Ukraine complex. The lack of the united arrangement actions were described of the viticulture and 
winemaking enterprises, unless they are the united enterprise. The first seek to sell their ready product for further processing as expensive as possible. The others seek to find the cheapest supplier of quality wine materials.

The major development trends were shown in the country viticulture-winemaking branch. This process leads to the problems in the complete branch. But this is only the part of the major problems for the viticulture-winemaking branch enterprises. The main difficulties for the industry were shown in the article. The set of those problems complicates the manufactured products issue of the field to the leading modern European markets. The question appears of the required analysis of needs and preferences of the foreign market.

The resent condition of the viticulture products market was reviewed in the article. This allows making some conclusions about the potential possibilities of the industry development. The main subjects and their rational cooperation will permit each to receive a positive effect.

The basic difficulty was shown in legislative field. The imperfect national legislation and unsystematic actions in some legislation acts leads to stagnation and decline in the industry. In this way the additional difficulties forms for the functioning of the viticulture-winemaking enterprises and agro-industrial complex in general.

In the article clearly were shown the area reduction of the grape plantings, decreased of the yield capacity and gross harvesting of the grapes. All of this is a consequence of irrational development of the industry. The acute problems of the industry were identified in the contemporary situation. The specific features of functioning of the viticulture-winemaking industry enterprises were depicted. The improvement ways of the industry state and action ways were suggested for the situation advance as at the enterprise level and at the level subcomplex.

Keywords: agroindustrial subcomplex, market, viticulture, winemaking, production, enterprise.

\section{References}

1. Istoriia vynohradarstva. (2014, June 10). Retrieved May 16, 2015, from http://vinograd.info/info/grozdyazdorovya/istoriya-vinogradarstva.html

2. Ctan vynorobnoi haluzi u sviti. (2013, April 23). Retrieved September 12, 2014, from http://takeprofit.org/economicnews.php

3. Harkusha, O. (2008). Problemy rozvytku vynohradarsko-vynorobnoho pidkompleksu Ukrainy. Ekonomika APK, (11), 3-5.

4. Balian, A. (2007). Stan yevropeiskoho vynohradarstva i napriamy pidvyshchennia efektyvnosti pidkompleksu v Ukraini. Ekonomika APK, (3), 16-22.

5. Serpukhovytyna, K. (2005). Sovremennue napravlenyia razvytyia vynohradarstva v uslovyiakh yntehratsyy otechestvennoi produktsyy v myrovoi runok. Vynodelye Y Vynohradarstvo, (1), 10-11.

6. Sydorenko, O., Matchyna, I., \& Buzny, A. (2006). Ekonomika vynohradno-vynorobnoho hospodarstva v rynkovykh umovakh Ukrainy (p. 312). Mykolaiv: MDAU.

7. Derzhavnyi komitet statystyky Ukrainy - 2014r. (2015, January 19). Retrieved August 13, 2015, from www.ukrstat.gov.ua

8. Zahoruiko, V. (2004). Mistse vyn Ukrainy na yevropeiskomu rynku. Visnyk Ahrarnoi Nauky, (12), 53-55.

9. Avidzba, A. (2006). Pidhotovka vynorobnoi haluzi do vstupu Ukrainy u SOT. Visnyk Ahrarnoi Nauky, (11), 5-10.

10. Pro vynohrad ta vynohradne vyno : Zakon Ukrainy. (2005). Vidomosti Verkhovnoi Rady Ukrainy, (31), 419.

Received 02 September 2015

Approved 21 September 2015

Available in Internet 26.12.2015 